\title{
Chemical and physiological aspects of isomers of conjugated fatty acids
}

\author{
Aspectos químicos e fisiológicos de isômeros conjugados de ácidos graxos
}

\author{
Eliane Bonifácio Teixeira de CARVALHO ${ }^{1}$, Illana Louise Pereira de MELO $^{1}$, Jorge MANCINI-FILHO ${ }^{1 *}$
}

\begin{abstract}
Conjugated fatty acid (CFA) is the general term to describe the positional and geometric isomers of polyunsaturated fatty acids with conjugated double bonds. The CFAs of linoleic acid (CLAs) are found naturally in foods derived from ruminant animals, meat, or dairy products. The CFAs of $\alpha$-linolenic acid (CLNAs) are found exclusively in various types of seed oils of plants. There are many investigations to assess the effects to health from CFAs consumption, which have been associated with physiological processes that are involved with non transmissible chronic diseases such as cancer, atherosclerosis, inflammation, and obesity. Conclusive studies about the CFAs effects in the body are still scarce and further research about their participation in physiological processes are necessary. This review aimed to discuss the influence of conjugated fatty acids on physiological processes in animal organism.

Keywords: conjugated linoleic acids (CLAs); conjugated $\alpha$-linolenic acids (CLNAs); health effects; analysis.
\end{abstract}

\section{Resumo}

Ácido graxo conjugado (AGC) é o termo geral usado para descrever os isômeros posicionais e geométricos dos ácidos graxos poliinsaturados com duplas ligações conjugadas. Os AGCs do ácido linoléico (ALCs) são encontrados naturalmente em alimentos derivados de animais ruminantes, carnes e produtos lácteos. Os AGCs do ácido a-linolênico (ALNCs) são encontrados exclusivamente em óleos de sementes de vários tipos de plantas. Desenvolvem-se muitas investigações com o objetivo de avaliar os efeitos do consumo de AGCs para a saúde, já que estes têm sido associados a processos fisiológicos relacionados com doenças crônicas não transmissíveis como câncer, aterosclerose, inflamação e obesidade. Estudos conclusivos sobre os efeitos dos AGCs no organismo humano ainda são raros e mais pesquisas sobre sua atuação em processos fisiológicos são necessárias. O objetivo desta revisão é discutir a influência dos ácidos graxos conjugados sobre os processos fisiológicos.

Palavras-chave: ácido linoléico conjugado (ALCs); ácido $\alpha$-linolênico conjugado (ALNCs); efeitos à saúde; análises.

\section{Introduction}

Lifestyle factors, including diet, influence the development of many non transmissible chronic diseases such as cancer, atherosclerosis, inflammation, and obesity (PARK; PARIZA, 2007). The human diet contains saturated, monounsaturated and omega-3 and omega-6 polyunsaturated fatty acids (YANG et al., 2009). In addition, two types of structurally related conjugated octadecaenoic acids, namely, conjugated linoleic acids (CLAs) and conjugated linolenic acids (CLNAs), are also present in the human diet although in small quantities (YANG et al., 2009). It has been noted that the quality of dietary lipids could be an important modulator in terms of the morbidity and mortality of these diseases (NAGAO; YANAGITA, 2005).

Polyunsaturated fatty acids (PUFAs), such as linoleic acid (LA, 18:2, $\omega-6)$, $\alpha$-linolenic acid (LNA, 18:3, $\omega$-3), and arachidonic acid (20:4, $\omega-6)$ are important for the maintenance of biofunctions in mammals. It should be also noted that other polyunsaturated fatty acids of omega-series such as eicosapentaenoic acid (EPA, 20:5, $\omega-3$ ) and docosahexaenoic acid (DHA, 22:6, $\omega-3)$ are correlated with a reduced risk of cancer and cardiovascular disease in clinical and animal studies (NAGAO; YANAGITA, 2008).

Recently, many studies are focused on 'conjugated fatty acids' (CFAs), which is the general term for a set of positional and geometric isomers of polyunsaturated fatty acids with conjugated double bonds (YUAN, G. F.; YUAN, J. Q.; LI, 2009; YUAN et al., 2009a). Interest in health benefits of CFAs is increasing since they have been shown to possess antioxidant, antitumor, immunomodulatory, and serum lipid-lowering activity (CAO et al., 2009). According to Tran et al. (2010), CFAs are known to have pharmacologic activities relevant to the prevention and treatment of atherosclerosis, obesity, cancer, and hypertension.

CFAs occur naturally as diene, triene, and tetraene compounds (YUAN, G. F.; YUAN, J. Q.; LI, 2009; YUAN et al., 2009a, c). Theoretically, several CFA isomers are possible with multiple combinations of numerical, positional, and geometrical configurations of conjugation in double bonds

Recebido para publicação em 6/4/2010

Aceito para publicação em 1/6/2010 (004871)

${ }^{1}$ Food and Experimental Nutrition Department, Faculty of Pharmaceutical Science, University of Sao Paulo - USP, Av. Prof. Lineu Prestes, 580, Bloco 14, CEP 05508-900,

São Paulo - SP, Brazil, E-mail: jmancini@usp.br

${ }^{*}$ A quem a correspondência deve ser enviada 
(NAGAO; YANAGITA, 2008). There are CFAs of linoleic acid and $\alpha$-linolenic (KOBA; BELURY; SUGANO, 2007). Figure 1 shows some of these isomers.

The conjugated fatty acids of linoleic acid (CLAs) comprise a group of positional and geometrical isomers of octadecadienoic acid (18:2 $\omega-6)$ in which the two double bonds are conjugated (without methylene interruption) and may have cis or trans configurations (WAHLE; HEYS; ROTONDO, 2004; TSOFLIOU et al., 2009). They have been detected in milk fat, cheese, and ruminant meat (NAGAO; YANAGITA, 2008; SANTOS-ZAGO; BOTELHO; OLIVEIRA, 2008). CLAs have been the subject of extensive investigations for their various biological activities. It has been reported that CLAs are antiatherosclerotic, anticarcinogenic, hypotensive,<smiles>CCCCCCCC/C=C/CCCCCCCC(=O)O</smiles><smiles>CCCCCC=CCC=CCCCCCCCC(=O)O</smiles><smiles>CCCCCCC=CC=CCCCCCCCCC(=O)O</smiles><smiles>CCCCCCC=CC=CCCCCCCCCC(=O)O</smiles>

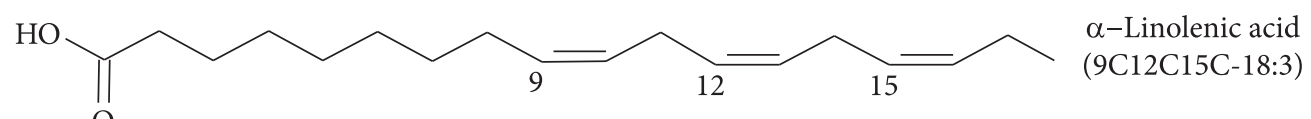<smiles>CCCCCC=CCC=CCC=CCCCCC(=O)O</smiles><smiles>CCCCCC=CC=CC=CCCCCCCCC(=O)O</smiles><smiles>CCCCC=CC=CC=CCCCCCCCCC(=O)O</smiles><smiles>CCCCC=CC=CC=CCCCCCCCC(=O)O</smiles><smiles>CCCCC=CC=CC=CCCCCCCCC(=O)O</smiles><smiles>CCCCC/C=C/C=C/C=C/CCCCCCC(=O)O</smiles><smiles>CCCCCC=CC=CC=CCCCCCCC(=O)O</smiles>

Figure 1. Structures of geometric and positional isomers of CFAs (adapted of TRAN et al., 2010). 
antilipogenic, immunoenhancing, and antioxidative (KOBA; BELURY; SUGANO, 2007; ANDREOLI et al., 2009; YANG et al., 2009).

The conjugated $\alpha$-linolenic acids (CLNAs) are other types of CFAs, which have 18 carbons and three double bonds conjugated together (YUAN et al., 2019a). The three double bonds present in CLNAs are primarily in positions $\Delta 9,11,13$ and $\Delta 8,10$, 12 and exist in both cis and trans geometrical isomer forms (KÝRALAN; GÖLÜKCÜ; TOKGÖZ, 2009; SASSANO et al., 2009). Many seed oils can be found in nature, and they have proved to be a potent suppressor of the growth of various human tumor cells and alter the lipid metabolism in animals (YANG et al., 2009; YUAN et al., 2009e).

In recent decades, interest in CFAs has increased due to their many bioactive properties related to health. There are many studies evaluating the beneficial effects of CLAs to the body, especially in some experimental animal models. However, some results are controversial and even show other adverse effects. In addition, the effects in humans are still questionable, and the biochemical mechanisms through which CLAs mediate the potential effects could produce undesirable metabolic alterations (ANDREOLI et al., 2009). In this sense, Agência Nacional de Vigilância Sanitária (ANVISA - Brazilian Health Vigilance Agency) banned the sale of supplements containing CLAs due to the lack of conclusive scientific studies regarding their safety and efficacy (BRASIL, 2007). Compared with CLAs, studies dealing with the physiological effects of CLNAs are still limited (KOBA; BELURY; SUGANO, 2007). There is no report that has estimated the current intake of CLNAs by humans and it is also uncertain whether CLNAs have health benefits similar to those of CLAs and LNA (YANG et al., 2005). In this study, we review the conjugated fatty acids in terms of their potential health effects.

\section{Conjugated Linoleic Acids (CLAs)}

\subsection{Structure, isomers and sources}

Numerous fatty acids with conjugated double bonds occur naturally in fats derived from ruminant animals, such as milk, milk products, meat, and meat products (BENJAMIN; SPENER, 2009). The term conjugated linoleic acid (CLA) refers generically to the class of positional and geometric conjugated dienoic isomers of linoleic acid (PARIZA; PARK; COOK, 2001) with double bonds at $[9,11],[10,12],[8,10],[7,9]$, and $[11,13]$ positions. Although a number of CLAs isomers are found in food (KRAMER et al., 1998; YUAN et al., 2009c), the primary focus of this research is on the two main isomers, cis 9 , trans 11 and trans 10, cis 12 (PARK; PARIZA, 2007).

The microbiota presented in the gastrointestinal tract of ruminant animals converts linoleic acid into different isoforms of CLAs through biohydrogenation. This process changes the position and configuration of the double bonds resulting in a single bond between two double bonds [cis9, trans 11 or trans10, cis12 octadecadienoic acid] (KENNEDY et al., 2010). The cis9, trans11 CLA isomer is produced through the biohydrogenation of unsaturated fatty acids by the bacterium
Butyrivibrio fibrisolvens in ruminants such as cows, sheep, goats, and camels (NAGAO; YANAGITA, 2008). An alternative source of cis 9 , trans 11 CLA isomer is by $\Delta-9$ desaturation of trans 11 vaccenic acid in mammalian tissues. The other main isomer of CLAs, trans10, cis12, is present in food in negligible amounts (PARK; PARIZA, 2007). The cis 9 , trans 11 isomer, also known as rumenic acid, is the predominant form of CLA found in naturally occurring foods. Cis 9 , trans 11 CLA comprises approximately $90 \%$ of the CLA found in ruminant meats and dairy products, and the trans 10 , cis 12 isomer comprises the remaining $10 \%$. Although several other isoforms of CLAs have been identified (trans 9 , trans 11 ; cis 9 , cis 11 ; trans 10 , trans 11 and cis 10 , cis 12 ), the cis 9 , trans 11 and trans 10 , cis 12 isomers appear to be the most biologically active (WALLACE et al., 2007; KENNEDY et al., 2010).

Several factors influence the CLAs content of food products, animal's diet, age or breed, and seasonal factors (RAINER; HEISS, 2004). The content of CLAs in milk ranged from 7.3 to $9.0 \mathrm{mg} . \mathrm{g}^{-1}$ of milk fat depending on the diets fed to cows (HUR; PARK; JOO, 2007), and within beef muscle concentrations of CLAs have been found to range from 0.37 to $1.08 \mathrm{~g} .100 \mathrm{~g}^{-1}$ (McAFEE et al., 2010). In the United States, it was estimated that a $70 \mathrm{~kg}$ individual should consume $3.0 \mathrm{~g}$ CLA/day to obtain beneficial effects from CLAs. This amount is about three times larger than that of the daily CLAs consumption of average adults (HUR; PARK; JOO, 2007). The average daily intake of CLAs is approximately 152 and $212 \mathrm{mg}$ for non-vegetarian women and men, respectively, and human serum levels range from 10 to $70 \mu$ mol.L ${ }^{-1}$ (KENNEDY et al., 2010). Large amounts may be consumed in the form of supplements since CLAs are claimed to cause weight loss, and supplement manufacturers recommend doses of 3.0-3.4 g/day for this purpose (WANDERS et al., 2010).

Linoleic acid can be converted to CLAs when a microbial or chemical reaction shifts the double bonds to form alternating double and single bonds, hence the term: conjugated linoleic acid (RAINER; HEISS, 2004). CLAs are produced commercially by alkaline isomerization of LA-rich oils and tend to contain an equimolar mixture of the cis9, trans 11 and trans 10 , cis 12 isomers (NAGAO; YANAGITA, 2008). There is no structural difference between naturally existing CLAs and synthetic CLA isomers (KRAMER et al., 1998; HUR; PARK; JOO, 2007).

Commercial preparations of CLAs are obtained from the linoleic acid of safflower or sunflower oils under alkaline conditions. This type of processing yields a CLAs mixture containing approximately $40 \%$ of the cis 9 , trans 11 isomer and $44 \%$ of the trans 10 , cis 12 isomer. Commercial preparations also contain approximately $4-10 \% \operatorname{trans} 9$, trans 11 CLA and trans 10 , trans 12 CLA, as well as trace amounts of other isomers (KENNEDY et al., 2010).

\subsection{Incorporation and metabolism}

Since their discovery, CLAs has been studied consistently and thoroughly in relation to metabolism, incorporation, and beneficial properties to health (SANTOS-ZAGO; BOTELHO; OLIVEIRA, 2008). The rate of CLAs metabolism in rats varies 
in different tissues and it is sensitive to experimental conditions, specially the dietary supply of linoleic acid. In adipose and mammary tissues, the metabolite content ranges from 5 to $15 \%$ of total CLAs and in plasma and liver from 10 to $30 \%$ (BANNI, 2002). CLAs, like other PUFAs, have been shown to be incorporated into membrane lipids with the extent of incorporation ranging from $<1$ to $>50 \%$ of total phospholipid fatty acids in various cells (SUBBAIAH et al., 2010).

The cis 9 , trans 11-18:2 and trans 10, cis12-18:2 were incorporated into all mouse tissues (liver, kidney, heart, perirenal adipose tissue, and spleen) examined in the group that received $1.0 \%$ CLA incorporated into the diet at levels ranging from 0.5 to $2.0 \%$ of tissue fatty acids. The proportions of 20:4n-6 and 22:6n-3 were significantly reduced in liver and kidney by CLAs feeding. In the heart, 22:6n-3 content was also reduced by CLA feeding although not significant (YUAN et al., 2009c).

Rats fed diets with 2\% CLAs isomer mixture had feed intake and body weight gain reduced, while addition of trans 10 , cis 12 CLA and Selenized-yeast resulted in the highest body weight gain. CLAs supplementation generally elevated the concentration of CLA isomers in heart and muscles significantly although cis9, trans 11 CLA accumulated preferentially. The dietary enrichment with CLA isomers caused a reduction in the $\Delta 9$-desaturase capacity. Furthermore, CLA isomers supplementation decreased the total fatty acids and PUFA concentrations in heart and muscles compared with control rats. Moreover, addition of CLA isomers interfered in the conversion of linoleic and linolenic acids to higher metabolites due to the competition of CLA isomers for the same enzymes such as $\Delta 6-, \Delta 5-, \Delta 4-$ desaturases, and elongase (CZAUDERNA; KOWALCZYK; KORNILUK, 2007).

The first step towards understanding the clinical effects of CLAs supplementation in humans is to determine which tissues may be enriched with these compounds in response to supplementation. Few studies have investigated the in vivo effects of CLAs supplementation in humans on tissue-specific CLA isomers incorporation (GOEDECKE et al., 2009). The results of studies carried out by Zlatanos, Laskaridis and Sagredos (2008) showed that CLAs had less effect on body fat than it was concluded from in vivo studies. However, Goedecke et al. (2009) have shown that a daily supplementation with $3.9 \mathrm{~g}$ CLAs (50:50, trans10, cis12: cis9, trans 11) during 12 weeks increases the content of the trans 10 , cis 12 isomer in the adipose tissue triacylglycerol and the cis9, trans 11 isomer tended to increase in skeletal muscle phospholipids.

Based on the results of the study conducted by Zlatanos, Laskaridis and Sagredos (2008) on a comparison between the plasma CLAs content of individuals who do not consume dairy products, and those who consume normal amounts of dairy products and individuals who consume CLAs supplement, the only CLA isomers that presented higher percentage than the detection limit ( $0.03 \%$ of total fatty acids) was the rumenic acid (cis9, trans 11 octadecadienoic acid). An interesting finding is that compared to the other two groups, the CLAs supplemented group show the highest rumenic acid content in plasma $(0.2 \%$ of total fatty acids). With regard to this result, it could be suggested that the lower limit of the plasma CLAs content is approximately $0.1 \%$ of total fatty acids.
As mentioned earlier, the incorporation of CLAs and some of their metabolites into neutral lipids results in the accumulation in tissues that are particularly rich in those lipids, such as mammary and adipose tissue (BANNI, 2002). The CLAs, when supplemented in the diet of the mother may be incorporated by cells in the mammary gland and secreted in the breast milk. Breast milk of women fed CLAs-enriched cookies (CLAs 1,912 mg) was analyzed and enrichment of CLAs in milk for 48 hours after ingestion of cookies enriched with CLAs was 2.9 times above the control (231 mg CLAs) (MOUTSIOULIS et al., 2008).

Data concerning the normal concentrations of CLAs in human plasma (ZLATANOS; LASKARIDIS; SAGREDOS, 2008), mammary gland, breast milk (MOUTSIOULIS et al., 2008), and on the incorporation of CLAs in adipose tissue and skeletal muscle (GOEDECKE et al., 2009) are scarse. This kind of information could help to estimate whether a person takes satisfactory amounts of CLAs with the diet or there is a need to increase them by supplementation given its potential effects on health-related parameters (ZLATANOS; LASKARIDIS; SAGREDOS, 2008).

\subsection{Health effects}

Since the discovery of CLAs as grilled beef-derived antimutagen in the 1980s, around 50\% of the studies concerning physiological functions of CFAs has been focused on their anticarcinogenic properties. However, there has been an increasing number of reports about antiobesity, antiatherogenic, antidiabetic, and hypotensive properties of CFAs in animal and human studies (NAGAO; YANAGITA, 2008; PARK, 2009; KENNEDY et al., 2010).

Researchers have been aware of CLAs for decades, but it became a subject of intense search only after the discovery that they have antimutagenic activity (PARK; PARIZA, 2007). They have also proved to have antiatherosclerotic (MITCHELL; McLEOD, 2008) and antiobesity properties (KENNEDY et al., 2010), besides improving insulin resistance in rats (ZHOU et al., 2008). More notably, they have been found to act as a potent cancer preventive agent in animal models of chemical carcinogenesis in skin, forestomach, colon, breast, and liver (PARK, 2009).

CLAs are known to exert several isomer-specific biological effects, but their mechanisms of action are unclear (PARK; PARIZA, 2007). More recently, CLAs have shown to undergo elongation and desaturation processes similar to those that occur with linoleic acid. This suggests that the CLAs mechanisms of action may be directly related to their properties and metabolism as unsaturated fatty acids (CZAUDERNA; KOWALCZYK; KORNILUK, 2007; SUBBAIAH et al., 2010).

\section{Weight gain, body composition, lipids}

profile, and insulin resistance index

Supplementation with a mixture of CLA isomers or trans 10 , cis12 CLA alone was capable to reduce adiposity in animal models, especially in rodents, but this effect was observed only in a few human studies. Potential mechanisms responsible for antiobesity properties of trans 10 , cis 12 CLA include: decrease energy intake by suppressing appetite; increase energy 
expenditure in white adipose tissue, muscle and liver or lean body mass; decrease lipogenesis or adipogenesis; increase lipolysis or delipidation; and apoptosis via adipocyte stress, inflammation, and/or insulin resistance (KENNEDY et al., 2010). CLAs reduced the total cholesterol (TC), triacylglycerides (TG), low-density lipoprotein cholesterol (LDL-C), and increased high-density lipoprotein cholesterol (HDL-C) in different animal models. CLAs affect these parameters through reduced blood pressure or involvement of peroxisome proliferator activated receptor (PPAR, key for lipogenesis), sterol regulatory element binding proteins (SREBPs, key for fatty acid synthesis and elongation), and/or steroyl-CoA desaturase (SCD, key for TG and cholesterol formation) (BHATTACHARYA et al., 2006; PARK, 2009).

Wistar rats supplemented with LA or CLAs for 42 days and the animals fed CLAs had a mean body fat reduction of $18 \%$ Water, whole body protein and ash content of rats supplemented with CLAs were statistically higher relative to control group (LA), but levels of triacylglycerols did not change after supplementation with CLAs (BOTELHO; SANTOSZAGO; OLIVEIRA, 2008). However, focusing on investigate the effects of CLAs at high fat levels, Andreoli et al. (2009) found hepatomegaly and exacerbation of lipid accretion to be a negative impact, but some positive aspects such as hypotriglyceridemia and protection against oxidative stress were also observed. Even the fat reduction is nutritionally important for weight control, the biochemical mechanisms whereby CLA mediates the potential effects could produce undesirable metabolic alterations.

Concerning the animal trials, CLAs in conjugation with saturated fats revealed both beneficial and deleterious biological effects. In the normal-weight Wistar rat fed a palm oil based diet, the administration of cis9, trans 11 CLA isomer increased the serum triacylglycerols, the size of adipocytes from epididymal, and retroperitoneal fat depots. In addition, a CLAs mixture of cis 9 , trans 11 and trans 10 , cis 12 isomers increased the glycerol membrane permeability of kidney proximal tubules, which may indicate an improvement of glycerol reabsorption pathway. The CLAs supplementation of diets rich in saturated fats and cholesterol has some beneficial effects in obese Zucker rats by increasing adiponectin and decreasing plasminogen activator inhibitor-1 (PAI-1) serum levels, as well as alleviating hepatic steatosis through hepatic lipids reduction. These results were highly associated with trans 10 , cis 12 isomers. However, this decrease does not seem to be enough to improve insulin sensitivity (MARTINS et al., 2010).

Some studies in rats and humans showed that CLAs promote insulin resistance, and there are conflicting reports on the effects of CLAs on peroxisomal proliferator activated receptor- $\gamma$ (PPAR $\gamma$ ) activation and expression. The supplementation with CLAs reduces body weight gain and white fat pad weight in the rats significantly; at the same time plasma free fatty acids (FFA), TG, TC, leptin, insulin, and glucose levels in the obese rats also decreased. Moreover, a supplementation with CLAs ameliorate insulin resistance by increasing the mRNA expression of PPAR $\gamma$, fatty acid binding proteins (ap2), fatty acid transporter protein (FATP), acyl-CoA synthetase (ACS), and adiponectin in the adipose tissues of obese rats (ZHOU et al., 2008).

\section{Antioxidant activity}

The effect of CLAs on lipid autoxidation processes has been studied extensively in recent years, with some ambiguous results, which do not allow clear conclusions about the antioxidant action. The presence of double bonds in the trans configuration of CLA isomers contribute to the stability of autoxidation, but considering that the conjugation of double bonds would be the beginning of lipid autoxidation, CLAs could act as pro-oxidant (SANTOS-ZAGO; BOTELHO; OLIVEIRA, 2008). According to Fagali and Catalá (2008), some authors showed that CLAs had antioxidant activity and it could be a possible explanation for the anticarcinogenic and antiatherogenic effects, while other investigations have pointed CLAs as pro-oxidants.

The in vitro studies that evaluate the oxidative stability of CLAs are conclusive with the fact that CLAs are more stable than other PUFAs that have no trans double bonds (SANTOSZAGO; BOTELHO; OLIVEIRA, 2008). However, Yang et al. (2009) compared the oxidative stability of individual CLA isomers with their corresponding nonconjugated, LA, and concluded that CLAs had greater oxidative instability than LA. Meantime, Fagali and Catalá (2008) demonstrated that CLAs also have antioxidant properties. Different concentrations of fat acid were investigated for free radical scavenging properties against the stable radical (DPPH $\bullet$ ). Both CLA isomers reacted and quenched $\mathrm{DPPH} \bullet$ at all tested concentrations (from 5 to $25 \mathrm{mM}$ ), while LA and methyl linoleate (LAME) did not show radical quenching activity even at the highest concentration. These data indicate that CLAs would provide protection against free radicals, but LA and LAME would not.

The evaluation of the CLAs antioxidant activity in animals is undertaken by the determination of thiobarbituric acid reactive substances (TBARS) and antioxidant enzymes, such as catalase (CAT), superoxide dismutase (SOD), and glutathione peroxidase (GSH-Px) (SANTOS-ZAGO; BOTELHO; OLIVEIRA, 2008). Mice fed a high fat diet and 3\% CLAs mixture showed that lipid peroxidation (LPO) using TBARS method, tended to normalization when compared with animals fed a high fat diet, and this result is related to a significant (85\%) increase in the glutathione content. The activity of GSH-Px and CAT was not increased by CLAs, these enzymes might contribute minimally to the lower LPO values observed (ANDREOLI et al., 2009). In another study conducted by our research group, rats were supplemented with CLAs in the concentrations of 1,2 and 4\% based on average daily consumption of diet by gavage, and the analysis of TBARS in serum indicated higher peroxidation in the $4 \%$ CLA group. The evaluation of antioxidant enzymes activity showed higher values of GSH-Px in the brain and the same was observed for SOD in the brain and liver for 2 and 4\% CLA groups indicating possible antioxidant activity (CARVALHO et al., 2009).

Another study conducted by Rahman et al. (2009) fed mice with $0.5 \%$ cis 9 , trans 11 CLA, $0.5 \%$ trans 10 , cis 12 CLA, or $0.5 \%$ CLA-mix for 6 months showed significantly higher muscle mass in both trans10, cis 12 CLA and CLA-mix groups. An enhanced mitochondrial ATP production, with higher membrane potential, and elevated muscle antioxidant enzymes (CAT and GSH-Px) production, accompanied by a slight 
increase in $\mathrm{H}_{2} \mathrm{O}_{2}$ production was noted in trans10, cis 12 CLA and CLA-mix groups when compared to control ( $10 \%$ corn oil) and cis9, trans 11 CLA groups. Oxidative stress, as measured by serum malondialdehyde and inflammation, as measured by LPS-treated splenocyte IL- 6 and TNF- $\alpha$, were significantly less in CLA isomers groups. These data indicate that CLAs may maintain redox balance during aging process (RAHMAN et al., 2009).

Research on CLAs has drawn much attention in the last years, but how these fatty acids of relatively simple structures could have such variety of functions remains unknown. Therefore, further studies are needed to clarify the mechanisms of CLAs activities (FAGALI; CATALÁ, 2008; SANTOS-ZAGO; BOTELHO; OLIVEIRA, 2008; ANDREOLI et al., 2009; PARK, 2009; RAHMAN et al., 2009).

\section{Molecular actions}

In vitro and in vivo studies have demonstrated a range of molecular mechanisms through which CLAs act including alteration of eicosanoids synthesis, reduction of NF- $\kappa B$ signalling proteins, and activation of PPAR $\gamma$ (REYNOLDS; ROCHE, 2010). It is suggested that CLAs may be involved in reducing eicosanoids production, interfering with cell signaling pathways, inhibiting DNA synthesis, enhancing apoptosis, and inhibiting angiogenesis as shown in reduced matrix metalloproteinase and vascular endothelial growth factors (BHATTACHARYA et al., 2006; PARK, 2009).

Zhou et al. (2008) demonstrate that CLAs are able to increase PPAR $\gamma$ activity. Furthermore, CLAs increase gene expression of PPAR $\gamma$ and PPAR $\gamma$ target genes ap2, FATP, FAT, and adiponectin in white adipose tissue, and reduce the PPAR $\gamma$ target genes and leptin levels. Because CLAs improve body fat and serum lipid biochemistry parameters, determine the mechanisms of action for CLAs can provide molecular targets that may have significant impact for many related lipid-dependent diseases, such as obesity and Type II diabetes. Thus, it will be of great interest to further understand the importance of CLAs as a $\operatorname{PPAR} \gamma$ modulator in relation to these diseases.

\section{Conjugated Linolenic Acids (CLNAs)}

\subsection{Structure, isomers and sources}

Conjugated linolenic acids (CLNAs) is a collective term for the positional and geometric isomers of octadecatrienoic acid (C18:3). The three double bonds present in CLNAs are primarily in positions $\Delta 9,11,13$ and $\Delta 8,10,12$ and exist in both cis and trans geometrical isomer forms (SASSANO et al., 2009). CLNAs have been reported to occur in terrestrial plant lipids, especially seed oils (KINAMI et al., 2007), present in high amounts accounting for $40-80 \%$ of total fatty acids (YANG et al., 2005; ARAO et al., $2004 \mathrm{~b}$ ). Five CLNA isomers occur as components of major seed oils of several plants: $\alpha$-eleostearic acid ( $\alpha$-ESA, cis 9 , trans 11 , trans13-18:3), punicic acid (PA, cis9, trans 11, cis13-18:3), calendic acid (trans8, trans10, cis12-18:3), jacaric acid (cis8, trans 10, cis12-18:3), and catalpic acid (trans9, trans 11 , cis 13 18:3) (IWABUCHI; KOHNO-MURASE; IMAMURA, 2003;
YUAN et al., 2009b, c). However, according to Sassano et al. (2009), seven species of CLNAs are commonly known, adding the $\beta$-eleostearic acid ( $\beta$-ESA, trans9, trans11, trans $13-18: 3$ ) and $\beta$-calendic acid (trans8, trans10, trans12-18:3) to those already mentioned above.

There are specific CLNA isomers in selected plant seeds, frequently as major fatty acids. Each of these plant seeds has a specific conjugase enzyme, which converts linoleic acid into CLNA. Therefore, each plant seed accumulates only a single CLNA isomer (KOBA; BELURY; SUGANO, 2007). For example, punicic acid is present in the pomegranate seed oil, $\alpha$-eleostearic acid in bitter gourd oil and tung seed oil, catalpic acid in catalpa seed oil, and calendic acid in pot marigold seed oil at about 72, $60-70,31$, and $33 \%$ of total fatty acid, respectively (NAGAO; YANAGITA, 2008). Therefore, these plant seed oils are suitable sources to investigate the physiological functions of individual CLNA isomers (KOBA; BELURY; SUGANO, 2007).

Among the seeds containing CLNAs, only those of Trichosanthes kirilowii Maxim (TK seeds) from China are edible. The punicic acid-harboring TK seeds, at about 32 to $40 \%$, are a popular snack food in China (MUKHERJEE et al., 2002; YUAN, G. F.; YUAN, J. Q.; LI, 2009; YUAN et al., 2009a, b).

Like CLAs, CLNAs can be also formed during the processing of vegetable oils as a result of the isomerization or dehydration of secondary oxidation products of LA and LNA (KINAMI et al., 2007; CAO et al., 2009; YANG et al., 2009). Although alkaline isomerization is effective for mass-production of CLNAs, identification of the detailed profiles of the synthetic CLNAs is difficult because the resultant mixture is composed of many different CLNA isomers. Nevertheless, synthetic CLNAs have proved to exert several physiological functions that are important and unique (KOBA; BELURY; SUGANO, 2007). Moreover, Coakley et al. (2009) showed that five bifidobacteria strains from human intestinal origin converted LNA to CLNAs and speculated that the ability of bifidobacteria originated from the human intestine to biosynthesis biologically active lipids such as $c i s 9$, trans 11 CLA and CLNA may be related to their suggested therapeutic effects.

\subsection{Incorporation and metabolism}

The study performed by Plourde et al. (2006) demonstrated that an equimolar mixture of two CLNA isomers, cis 9 , trans 11 , cis15-18:3 and cis9, trans13, cis15-18:3 had the same apparent absorption efficiency than cis 9 , trans 11-18:2 when ingested under nutritional and physiological conditions. Both CLNA isomers were mainly incorporated into neutral lipids, but they were not metabolized to CLAs. They were metabolized by the elongation/desaturation pathway similar to LNA with the cis9, trans 11, cis15-18:3 isomer being converted into conjugated 22:6 n-3 and with the cis9, trans 13 , cis 15-18:3 isomer being converted into conjugated 20:5n-3. Yuan et al. (2009e) showed that the proportion of 22:6n-3 was significantly increased in liver phospholipids of mice supplemented with $1 \%$ PA, but not with a-ESA, for 6 weeks. This is consistent with the study of Koba et al. (2007) showing that feeding 0.5\% pomegranate seed oil containing PA increased the proportion of 22:6n-3 
in mouse liver. However, Noguchi et al. (2001) found that the supplementation with bitter melon seed oil containing a-ESA for 4 weeks increased the proportion of 22:6n-3 in rat liver.

Nevertheless, most studies show that CLNAs are well absorbed into the body and metabolized to CLA in vivo (TSUZUKI et al., 2004b, 2006; KOBA; BELURY; SUGANO, 2007; YUAN, G. F.; YUAN, J. Q.; LI, 2009). These findings have led to an increased interest in CLNAs.

Studies have shown that $\alpha$-ESA and PA were detected in rodents fed $\alpha$-ESA and PA, respectively, and the cis 9 , trans 11 18:2 was detected in the tissues (liver, kidney, heart, adipose tissue, spleen, mammary gland, and intestine) of both groups (TSUZUKI et al., 2004b, 2006; YANG et al., 2009; YUAN et al., 2009c, d, e). Therefore, a-ESA or PA could exert beneficial activities through the effect of their metabolite (cis9, trans1118:2) or the own compounds ( $\alpha$-ESA or PA) per se. Those authors also speculated that CLNAs can be converted to CLA by a $\Delta 13$ - saturation reaction carried out by an NADPHdependent enzyme that is either a novel enzyme recognizing conjugated trienoic acid or the enzyme active in the leukotriene $\mathrm{B} 4$ reductive pathway.

Tsuzuki et al. (2006) investigated the absorption and metabolism of CLNAs ( $\alpha$-ESA and PA) in rat intestine using a lipid absorption assay in lymph from the thoracic duct. The results indicate that the $\alpha$-ESA and PA are slowly absorbed in an unchanged state in the rat intestine, and a portion of these fatty acids is quickly converted to CLA. Similar results were also found by Yuan, G. F., Yuan, J. Q. and LI (2009), which showed that PA was also quickly converted into cis9, trans11 CLA in different rat tissues and plasma. They observed that no CLA and PA were detected immediately after treatment (zero-time), but both were detected in the rat tissues and plasma $4,8,12$, and 24 hours after treatment (each rat was fed about $645 \mathrm{mg}$ of PA). PA and CLA in the liver and plasma were higher than in the brain, heart, kidney, and adipose tissue.

Yuan et al. (2009d, e) showed still that the accumulation of PA in the tissues examined was significantly higher than $\alpha$-ESA and found that the relative conversion rate of $\alpha$-ESA into cis 9 , trans11-18:2 was significantly higher than that of PA into cis9, trans11-18:2 in liver TG and phospholipids, provided further evidence that a-ESA is more effectively saturated in the $\Delta 13$ double bond than PA in mouse liver TG and phospholipids. The highest conversion rate of $\alpha$-ESA was found in the adipose tissue (91.8\%), spleen (91.4\%) and kidney (90.7\%), and the lowest in heart $(84.6 \%)$; the highest conversion rate of PA occurred in the liver (76.2\%) and the lowest occurred in the heart (54.5\%) (YUAN et al., 2009d). The only difference between $\alpha$-ESA and $\mathrm{PA}$ is the geometrical structure of the $\Delta 13$-double bond since a-ESA is a trans double bond, whereas that of PA is a cis double bond. Therefore, it is possible that the geometrical structure of the $\Delta 13$-double bond affects the saturation activity of the enzyme, and the difference in the conversion rates of $\alpha$-ESA and PA in vivo was due to substrate-specific effect of this enzyme (YUAN, G. F.; YUAN, J. Q.; LI, 2009); YUAN et al., 2009e). It is speculated that the liver could be the source of the enzymes responsible for the conversion of CLNAs to CLA. However, further studies are needed to provide a clearer understanding of this mechanism of CLNAs metabolism (YUAN, G. F; YUAN, J. Q.; LI, 2009). These results indicate that CLNA isomers are discriminately metabolized and incorporated.

Cao et al. (2009) reported that the incorporation of three CLNA isomers into the milk in rats was selective. A mixture of CLNA isomers including cis9, trans11, trans13-18:3, trans9, trans 11 , trans 13-18:3 and cis9, trans 11, cis13-18:3 was added into the maternal diets, and the results showed that cis 9 , trans 11 , cis 13 CLNA (one trans bond) was the most incorporated into the milk followed by cis9, trans 11 , trans 13 (two trans double bonds) and trans 9 , trans 11 , trans 13 (three trans double bonds) in a decreasing order. The results suggest that the oxidoreductase of $\Delta 13$-saturation preferred substrates with a trans configuration. The most interesting observation was that feeding maternal rats with CLNAs diet could produce milk containing CLA indicating that CLNAs were converted into CLA.

The observation that CLNAs could be converted into cis9, trans 11 CLA has gained increased importance since it has been demonstrated that cis9, trans 11 CLA can exert many biological activities. Since the $\alpha$-ESA and PA are present in some plant seeds, such as Trichosanthes kirilowii (TK), pomegranate, and bitter melon seed in large amounts and could be purified relatively easily, they could be alternative sources for obtaining the health effects of CLAs (YUAN, G. F.; YUAN, J. Q.; LI, 2009; YUAN et al., 2009c). Moreover, natural resources containing CLNAs could be a potential dietary source of CLA and are expected to be useful as a functional food and nutraceutic.

There are few literature data on the incorporation and metabolism of CLNAs in humans. Yuan et al. (2009a) investigated the incorporation and metabolism of PA in healthy young humans $(n=15)$. After daily consumption of TK seeds containing $3 \mathrm{~g}$ of PA for 28 days, the proportion of PA increased $0.47 \%$ in plasma and $0.37 \%$ in red blood cell membranes ( $\mathrm{RBCM}$ ), respectively. Moreover, the proportion of cis9, trans11-18:2 was increased from 0.05 to $0.23 \%$ in plasma and from 0.03 to $0.17 \%$ in RBCM, respectively. The results suggest that PA can be effectively incorporated into human plasma and RBCM, and it is also associated with the increasing proportion of cis 9 , trans11-18:2 in humans, presumably as a result of the metabolism by a saturation reaction.

The biological impact of these fatty acids ingestion needs to be considered since they could interfere with lipid metabolism and exert other health effects.

\subsection{Health effects}

Information concerning the biological activity of CLNAs is scarce, except for some studies which have demonstrated that CLNAs have a cytotoxic effect on cultured human tumor cells (IGARASHI; MIYAZAWA, 2005; YASUI et al., 2005), inhibits carcinogenesis (KOHNO et al., 2004a, b; TSUZUKI et al., 2004a; TSUZUKI; KAWAKAMI, 2008), and alters lipid metabolism in animals (YANG et al., 2005; YAMASAKI et al., 2006; KOBA et al., 2007; LAM et al., 2008). Some mechanism of the antitumor effects of CLNAs is thought to be the apoptosis 
induction via lipoperoxidation (IGARASHI; MIYAZAWA, 2000; TSUZUKI et al., 2004a).

It has already been found that different CLNA isomers exert different bioactivities (SUZUKI et al., 2001), but their mechanisms of action are unclear. Furthermore, studies have shown that CLNAs could be metabolized into CLA in vivo (TSUZUKI et al., 2004b, 2006; YUAN et al., 2009c) suggesting that the health benefits may be due to the CLA.

Weight gain, body composition, lipids

profile, and insulin resistance index

Some studies report controversial results for the role of CLNAs in weight gain, body composition, plasma lipids, and insulin resistance index.

Koba et al. (2002) investigated how CLNAs affect body fat mass in rats and concluded that feeding CLNAs resulted in reduction in weight of adipose tissue. In contrast, supplementation with 1\% CLNAs ( $\alpha$-ESA and/or PA) for 6 weeks did not significantly affect the food intake, body, and tissue weights of mice (YUAN et al., 2009c, e). Yamasaki et al. (2006) reported that body weight and adipose tissue were not affected in $\mathrm{C} 57 \mathrm{BL} / 6 \mathrm{~N}$ mice fed experimental diets containing 0.12 and $1.2 \%$ pomegranate seed oil (PSO) rich in PA for 3 weeks. Arao et al. (2004a) showed that feeding a diet supplemented with 9\% safflower oil and 1\% PSO for two weeks did not affect the abdominal white adipose tissue weight in Otsuka Long-Evans Tokushima Fatty (OLETF) rats. However, Koba et al. (2002) showed that CLNAs reduce the perirenal adipose tissue weight in a larger extent when compared with LA, CLA, and LNA in Sprague-Dawley rats. The same group recently showed that supplementation with PSO decreased the weight of perirenal adipose tissue in ICR CD1 mice in a dose dependent manner after four weeks of feeding (KOBA et al., 2007). Chardigny et al.

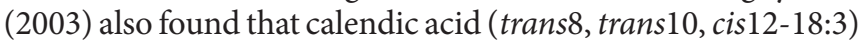
significantly decreased the body fat content in male mice.

Some studies have found that supplementation with CLNAs significantly decreases serum TC (KOBA et al., 2002; DHAR et al., 2006), apoB-100 (ARAO et al., 2004b), and hepatic TG (ARAO et al., 2004a, b). However, Yang et al. (2005) showed that feeding 12.2-12.7 g. $\mathrm{kg}^{-1} \mathrm{PA}$ and $\alpha$-ESA for 42 days did not affect serum TG, TC, HDL-C, and non-HDL-C levels, but it exhibited significant effects in decreasing the liver TC in hamsters. On the other hand, Yamasaki et al. (2006) reported significant increases in serum TG and phospholipid levels but not in TC in mice fed 0.12 and 1.2\% PSO. Koba et al. (2007) did not find any significant effect of PA on serum lipids in mice, but the liver TG levels were significantly decreased when compared to the control group. This observation is in agreement with results by Yuan et al. (2009e) who did not observe significant differences in TG, TC, HDL-C and LDL-C levels in plasma among mice fed control diet or fed $\alpha$-ESA or PA for six weeks either, but the liver TG levels were significantly decreased compared to the control group.

There are few data on the effect of CLNAs on lipid profiles in human subjects. Mirmiran et al. (in press) concluded in their study that PSO consumption in hyperlipidaemic subjects did not alter TC and LDL-C but reduced TG and TG:HDL-C ratio during 4 weeks. Further longer studies using larger samples are necessary to confirm the effects of PSO and its related mechanisms.

Hontecillas et al. (2008) showed that dietary supplementation of mice with catalpic acid, an isomer of CLNA, for 78 days improved fasting glucose and insulin concentrations and enhanced the ability to normalise plasma glucose concentrations following a glucose tolerance test in a model of diet-induced obesity. These findings were also found by the same authors when evaluating mice receiving PA, another CLNA isomer (HONTECILLAS et al., 2009). McFarlin, Strohacker and Kueht (2009) concluded in their study that PSO intake (average consumption of $61.79 \mathrm{mg}^{\mathrm{d}} \mathrm{d}^{-1}$ ) was associated with an improvement in insulin sensitivity in CD-1 mice suggesting that the risk of developing type 2 diabetes may have been reduced. However, dietary supplementation with Trichosanthes kirilowii Maxim (TK seeds) rich in PA for 28 days did not have a significant effect on fasting serum concentrations of insulin and glucose, neither on insulin sensitivity, assessed using the specific HOMA-IR index in humans (YUAN et al., 2009c).

\section{Antioxidant activity}

Nutritional antioxidants in diseases related to oxidative stress have gained a great interest in recent years (SAHA; GHOSH, 2009). Studies showed that CLNAs suppress the growth of tumor cells through a mechanism that involves lipoperoxidation (IGARASHI; MIYAZAWA, 2000; TSUZUKI et al., 2004a). Grossmann et al. (2009) found that when breast cancer cells were treated with $\alpha$-ESA in the presence of the antioxidant $\alpha$-tocotrienol $\left(20 \mu \mathrm{mol} . \mathrm{L}^{-1}\right)$, the growth inhibition and apoptosis effects of $\alpha$-ESA were lost. Thus, they concluded that $\alpha$-ESA can block breast cancer cell proliferation and induce apoptosis through a mechanism that may be oxidation dependent. Although the mechanism of CLNAs bioactivities is considered to be related to oxidation, many controversial results are reported (YANG et al., 2009). Dhar et al. (2006) concluded that dietary CLNA exerts antioxidant activity, as evidenced by reduced lipid peroxidation in chemically induced diabetes mellitus.

The non conjugated unsaturated fatty acid structures are more susceptible to oxidation process since the presence of methylene carbons between the double bonds facilitates the removal of hydrogen atom and the formation of free radical, which is the initial step for oxidation (MANCINI; MANCINIFILHO, 2005). Yang et al. (2009) studied the oxidative stability of individual CLNA isomers comparing the oxidative stabilities with their corresponding nonconjugated LNA, and concluded that CLNAs are more susceptible to autoxidation than LNA. Among the three groups of CLNA isomers, the $t, t, t$-CLNA isomers had greater stability followed by $c, t, t$-CLNA and $c, t, c-$ CLNA isomers in decreasing order. The oxidation stability of CLNA isomers in each geometrical group was also dependent on the location of the three conjugated double bonds. Evaluating the oxidative stability of PSO (rich in PA) in Rancimat ${ }^{\circ}$ system, the oxidation induction time for the PSO was $0.54 \pm 0.05$ and linseed oil (rich in LNA) was $0.67 \pm 0.00$ hours, which differed significantly from the soybean oil whose oxidation induction 
time was $7.65 \pm 1.19$ hours. This result was expected since the PA and the LNA have greater degree of unsaturation in their structure which makes them more susceptible to oxidation (MELO et al., 2010). These results indicated that CLNAs may influence the oxidative deterioration of vegetable oils despite their presence (KINAMI et al., 2007).

The stability of PSO was also analyzed in the systems: testing radical 2,2-diphenyl-1-picrylhydrazyl (DPPH•) and cooxidation of $\beta$-carotene/linoleic acid. The results showed that the PSO was able to reduce the DPPH•, with $\mathrm{IC}_{50}$ (concentration capable to reduce $50 \%$ of the radical) of $3.77 \mathrm{mg}$, while that of Butilhydroxytolueno (BHT) was $0.26 \mathrm{mg}$. With regard to the system $\beta$-carotene/linoleic acid, the PSO had $21 \%$ of oxidation resistance (MELO et al., 2010). Schubert, Lansky and Neeman (1999) reported an approximately $40 \%$ inhibition of oxidation for the PSO; however the authors correlate this value with the presence of phenolic compounds with antioxidant activity.

In vivo, CLNAs increased the level of plasma hydroperoxide and live lipid oxidation significantly (NOGUCHI et al., 2001). In contrast, Dhar, Ghosh and Bhattacharyya (1999) have previously reported that the CLNA present in karela seed oil has scavenging action against lipid peroxidation, using the TBARS method, on rats for 4 weeks and that $0.5 \%$ a-ESA in the dietary lipid was the optimal dose. Mukherjee et al. (2002) examined the activity of PA supplemented in the diet of rats at various concentrations, and it also appeared to be efficient as an antioxidant, with maximum antioxidant activity of $0.6 \% \mathrm{PA}$. It is likely that under these conditions CLNAs may have reduced the formation of hydro-peroxides by lowering the formation of free radicals and peroxidation of PUFAs in erythrocyte membrane and other lipids; another possible explanation may be that the biohydrogenation or free radical addition to one of the conjugated double bonds of CLNAs might have taken place resulting in the formation of conjugated dienes that might have acted as antioxidants (DHAR; GHOSH; BHATTACHARYYA, 1999; SAHA; GHOSH, 2009).

Dhar et al. (2006) investigated the dietary effect of CLNAs on lipid peroxidation in alloxan-induced diabetes mellitus in rats. LDL- and erythrocyte membrane lipid peroxidation were reduced significantly in each of the experimental groups (0.5\% CLNAs, $0.15 \%$ a-tocopherol, and $0.25 \%$ CLNA + $0.15 \%$ a-tocopherol) versus the control group. The CLNAs + a-tocopherol diet induced a greater reduction in the membrane lipid and liver lipid peroxidation than the a-tocopherol diet alone.

Saha and Ghosh (2009) analyzed the influence of two isomers of CLNA ( $0.5 \%$ of total lipid given for 15 days) in antioxidant activity against arsenic induced oxidative stress. The result suggests that sodium arsenite changed the activities of antioxidant enzymes in the plasma, erythrocyte lysate, liver, and brain homogenate, while $\alpha$-ESA and PA increased activities of SOD, CAT, and GSH-Px and decreased the activity of nitric oxide synthase (NOS) to normal level. Overall, there was some difference in the effectiveness of the two isomers, which is due to their antagonistic cis-trans molecular arrangement. In this study, $\alpha$-ESA acid was more efficient as antioxidant than PA due to its higher trans content.

\section{Molecular actions}

The regulation of molecular actions by natural dietary components represents an alternative therapeutic strategy in inflammatory disorders, bowel diseases, rheumatoid arthritis, atherosclerosis, metabolic syndrome, and ischemia/reperfusion injury that are recognized as major health problems worldwide. A common characteristic of these diseases is the excessive production of pro-inflammatory mediators such as TNFa, GM-CSF, IL-1, IL-6, IL-8, leukotriene B4, and PAF, the presence of highly activated inflammatory cells such as neutrophils, monocytes, and macrophages, and the excessive production of reactive oxygen species (ROS) (BOUSSETTA et al., 2009). These authors evaluated the effect of PA on TNFa-induced neutrophil hyperactivation in vitro and on colon inflammation in vivo and concluded that PA exerts a potent anti-inflammatory effect through the inhibition of TNFa-induced priming of ROS production and myeloperoxidase (MPO) release by neutrophils thus resulting in low tissue damage.

Bassaganya-Riera et al. (2010) observed in mice that PA intake upregulated colonic expression of $\operatorname{PPAR} \delta$, keratinocyte growth factor, and the orphan nuclear receptor ROR $\gamma t$ expression and suppressed colonic and M1 macrophage-derived TNF- $\alpha$. In the mesenteric lymph nodes (i.e., mucosal inductive sites), PA increased the levels of IL-17 and IFN- $\gamma$ in CD8 ${ }^{+}$T cells. The authors provided molecular evidence in vivo suggesting that PA modulates mucosal immune responses and ameliorates gut inflammation through PPAR $\gamma$ and $\delta$-dependent mechanisms. In the same direction, Hontecillas et al. (2009) investigated whether the PA activates PPAR $\gamma$, an important therapeutic target for diabetes and inflammation. Dietary PA decreased fasting plasma glucose concentrations, improved the glucose-normalizing ability, suppressed NF- $\kappa$ B activation, TNF- $\alpha$ expression and upregulated PPAR $\alpha$ - and $\gamma$-responsive genes in skeletal muscle and adipose tissue of mice. Their findings demonstrated that PA binds and robustly activates PPAR $\gamma$, increases PPAR $\gamma$-responsive gene expression, which could be important to ameliorate diabetes and inflammation (HONTECILLAS et al., 2009). The same authors have previously shown that dietary supplementation of mice with catalpic acid, another isomer of CLNA, upregulated PPAR $\alpha$ and PPAR $\alpha$-responsive genes in white adipose tissue (WAT), whereas PPAR $\gamma$ and $\delta$ expression were not significantly affected by catalpic acid in WAT. These data suggest that the metabolic effects of catalpic acid on glucose and lipid metabolism may be mediated through a PPAR a-dependent mechanism (HONTECILLAS et al., 2008). Moreover, studies show that bitter gourd seed oil (BGO), which contains a high level of cis9, trans11, trans13 CLNA, increases PPAR $\gamma$ mRNA and protein levels in Caco- 2 cells and in rats (KOHNO et al., 2004b; YASUI et al., 2005). Moreover, tung oil containing $\alpha$-ESA activates PPAR $\gamma$ in human endothelial cells of umbilical vein (TSUZUKI; KAWAKAMI, 2008).

Tran et al. (2010) evaluated pomegranate (Punica granatum) seed linolenic acid isomers as selective estrogen receptor modulators (SERMs) in vitro. PA inhibited $\left(\mathrm{IC}_{50}\right)$ estrogen receptor (ER) $\alpha$ and $\beta$ at 7.2 and $8.8 \mathrm{mM}$, respectively; $\alpha$-ESA inhibited ER $\alpha / E R \beta$ at $6.5 / 7.8 \mathrm{mM}$, so both PA and $\alpha$-ESA are SERMs. Therefore, PA, as principal components of PSO, acts as 
SERMs and, potentially, will also act in the future as effective breast cancer chemopreventive agents.

These natural dietary compounds may provide a novel alternative therapeutic strategy in many diseases such as inflammatory diseases and cancer (BOUSSETTA et al., 2009).

\section{CLAs versus CLNAs}

The study performed by Plourde et al. (2006) demonstrated that an equimolar mixture of two CLNA isomers, cis9, trans 11 , cis15-18:3 and cis 9 , trans13, cis15-18:3 has the same apparent absorption efficiency than cis9, trans11-18:2 when ingested under nutritional and physiological conditions. According to Yuan et al. (2009c), the cis9, trans11-18:2 and trans10, cis12-18:2 were incorporated into all mouse tissues examined in the CLAs group at levels ranging from 0.5 to $2.0 \%$ of tissue fatty acids, whereas the $\alpha$-ESA and PA were detected in all mouse tissues examined in the $\alpha$-ESA and PA groups, respectively, at levels ranging from 0.1 to $1.3 \%$. Furthermore, CLAs were detected in all tissues examined in both $\alpha$-ESA and PA groups with levels ranging from 0.5 to $3.5 \%$ of tissue fatty acids.

It was found that supplementation of CLNAs or CLAs in the maternal dietary fat at 1 and $2 \%$ levels in diet led to the incorporation of only 0.98 to $1.71 \%$ CLNAs in milk fat in rats, contrasting with the incorporation of 4.21 to $8.66 \%$ CLAs in milk fat, suggesting that both CLAs and CLNAs were able to transfer from maternal diet to the milk. These results showed that transfer of CLNAs from maternal diets was quantitatively minor compared with that of CLAs (CAO et al., 2009).

Studies show that CLNAs are more effective than CLAs in reducing body fat mass in rodents (KOBA et al., 2002, 2007). However, Chardigny et al. (2003) found that calendic acid (trans 8 , trans 10 , cis $12-18: 3$ ) significantly decreased the body fat content in male mice although it was less effective than trans10, cis12-18:2. Yuan et al. (2009e) reported that no significant differences in food intake and final body weight were observed among the groups of mice fed either a control diet or one of experimental diets supplemented with $1 \%$ a-ESA, $1 \%$ PA, or 1\% CLA in the form of TG for 6 weeks. In contrast, the weights of the perirenal and epididymal adipose tissues were significantly decreased while the liver TG level and weight was significantly increased in mice fed a diet supplemented with CLAs (YUAN et al., 2009e). Lam et al. (2008) examined the relative hypocholesterolemic activity of CLAs, CLNAs, and their corresponding nonconjugated, LA and LNA. They found that LA, CLAs and LNA were hypocholesterolemic, while CLNAs had no effect on blood cholesterol level in hamsters fed a high cholesterol diet. This could be explained, at least in part, because LA, CLA, and LNA, but not CLNA, inhibited intestinal cholesterol acyltransferase (ACAT) activity and interfered with neutral sterol absorption. Although the results are still contradictory and inconclusive, the findings seem to indicate that CLNAs modulate body fat and lipid metabolism differently from CLAs.

Yang et al. (2009) studied the oxidative stability of individual CLA and CLNA isomers comparing the oxidative stabilities with their corresponding nonconjugated counterparts, LA, and LNA and concluded that, CLAs and CLNAs had greater oxidative instability. Compared with CLAs, CLNAs was more susceptible to oxidative degradation implying that the oxidative stability of CFAs decreases with an increase in the number of conjugated double bonds.

\section{Analysis methods}

The biological activities showed in both cells and in vivo studies arouse interest to separate and identify these CFAs.

The multiple physiologic effects reported for CLAs could be the result of interactions of the biologically active CLA isomers with numerous metabolic signaling pathways. Hence, studies to define beneficial and detrimental effects of each individual CLA isomers are needed and should be undertaken (La FUENTE; LUNA; JUÁREZ, 2006). Like CLAs, CLNA isomers showed different physiologic effects, and minor structural differences among CLNA isomers make their separation, identification, and quantification difficult. In this regard, it is imperative to develop a reliable method of separation and characterization of individual CFA isomers in complex mixtures such as synthetic products and biological materials (CAO et al., 2006).

In CFAs analysis, it is important that the geometrical and positional isomers are separated and quantified avoiding additional isomerization during any derivatization steps (CHRISTIE; DOBSON; ADOLF, 2007). The traditional analysis of fatty acids from lipids involves derivatization to form less polar and more volatile compounds. Preparation of volatile derivatives is often the step prior to the fatty acids profile analysis by chromatography (La FUENTE; LUNA; JUÁREZ, 2006). The most extended procedure consists in transforming fatty acids from glycerides into Methyl Esters (ME). Alkalicatalyzed methylation methods (using $\mathrm{NaOCH}_{3}$ or $\mathrm{KOH}$ in methanol at room temperature) are considered the most reliable for determining the distribution of CFA isomers because they cause no isomerization and produce no methoxy artifacts. Acid-catalyzed methods, employing $\mathrm{BF} 3, \mathrm{HCl}$ or $\mathrm{H}_{2} \mathrm{SO}_{4}$, favor extensive isomerization of conjugated dienes and trienes and contribute to forming allylic methoxy artifacts (La FUENTE; LUNA; JUÁREZ, 2006; CHEN et al., 2007; SASSANO et al., 2009).

Gas chromatography (GC) and silver-ion impregnated high-performance liquid chromatography ( $\mathrm{Ag} \pm \mathrm{HPLC}$ ) are the most common techniques in the analysis of CFA isomers (CHEN et al., 2007; CHRISTIE; DOBSON; ADOLF, 2007; SASSANO et al., 2009).

Analysis on capillary columns GC-FID (equipped with a flame ionization detector) and polar phases is the common approach used for the analysis of trans fatty acids, CP-Sil 88TM, SP2380TM or BPX-70TM $(100 \mathrm{~m})$. The most commonly gases used as carrier gas are Helium or Nitrogen (KRAMER et al., 2004; La FUENTE; LUNA; JUÁREZ, 2006; CHRISTIE; DOBSON; ADOLF, 2007; YANG et al., 2009). In addition, Ag \pm HPLC has proved very useful for the separation of geometrical and positional isomers both on analytical and preparative scales using a silver ion-impregnated column and diode array detector 
(KRAMER et al., 2004; CAO et al., 2006; CHRISTIE; DOBSON; ADOLF, 2007; SASSANO et al., 2009).

Fatty acid methyl esters (FAMEs) are identified by comparison of their retention times with individual reference Standards. The CLNAs are identified using the major fatty acid extracted from their corresponding oils with hexane and esterified to the methyl esters (KÝRALAN; GÖLÜKCÜ; TOKGÖZ, 2009). Furthermore, a known amount of internal standard (for example, C17:0) is added to each test sample fatty acid (TSUZUKI et al., 2004a).

However, to resolve and determine individual CLNA isomers present in natural mixtures that have only minor positional and geometrical differences in their structure, the separation and confirmation of all (seven) isomer forms by GC analysis is difficult. Thus, a combination of gas chromatographymass spectrometry (GC-MS) or characterization by nuclear magnetic resonance $\left({ }^{1} \mathrm{H}\right.$ NMR or ${ }^{13} \mathrm{C}$ NMR) is necessary (CAO et al., 2006; SASSANO et al., 2009).

\section{Conclusions}

There are no consensus in the literature regarding the effects of CFAs on animal and human organisms. Animal studies are inconclusive and often contradictory, and human studies are scarce. In addition, some effects observed in animal studies are not the same verified in humans. Although the marketing of supplements containing CLAs have been banned by ANVISA in Brazil, in some continental Europe countries, their use is not restricted. Therefore, further studies are needed in order to elucidate the mechanisms and physiological effects of the CFAs to provide greater safety and establish recommendations with respect to their use.

\section{Acknowledgements}

The authors are grateful for the financial support provided by the foundations CAPES (Coordenação de Aperfeiçoamento de Pessoal de Nivel Superior) the Brazilian research supporting foundation and FAPESP (Fundação de Amparo à Pesquisa do Estado de São Paulo) the State of São Paulo Research Foundation- processes No 09/51891-7 and 09/51890-0.

\section{References}

ANDREOLI, M. F. et al. Effects of dietary conjugated linoleic acid at high-fat levels on triacylglycerol regulation in mice. Nutrition, v. 25, n. 4, p. 445-452, 2009.

ARAO, K. et al. Dietary effect of pomegranate seed oil rich in 9cis, 11trans, 13cis conjugated linolenic acid on lipid metabolism in obese, hyperlipidemic OLETF Rats. Lipids in Health and Disease, v. 3, p. 24-30, 2004a.

ARAO, K. et al. The 9cis,11trans,13cis isomer of conjugated linolenic acid reduces apolipoprotein B100 secretion and triacylglycerol synthesis in HepG2 cells. Bioscience, Biotechnology, and Biochemistry, v. 68, n. 12, p. 2643-2645, 2004 b.

BANNI, S. Conjugated linoleic acid metabolism. Current Opinion in Lipidology, v. 13, n. 3, p. 261-266, 2002.

BASSAGANYA-RIERA, J. et al. Punicic acid modulates mucosal immune responses and prevents gut inflammation through PPAR $\gamma$ and $\delta$-dependent mechanisms. The FASEB Journal, v. 24, n. 1 , 2010.

BENJAMIN, S.; SPENER, F. Conjugated linoleic acid as functional food: an insight into their health benefits. Nutrition and Metabolism, v. 6, p. 36-48, 2009.

BHATTACHARYA, A. et al. Biological effects of conjugated linoleic acids in health and disease. The Journal of Nutritional Biochemistry, v. 17, n. 12, p. 789-810, 2006.

BOTELHO, A. P.; SANTOS-ZAGO, L. F.; OLIVEIRA, A. C. Conjugated linoleic acid supplementation modified the body composition and serum leptin levels in weaning rats. Archivos Latinoamericanos de La Sociedad Latinoamericana de Nutrícion, v. 58, n. 2, p. 156-163, 2008.

BOUssetTA, T. et al. Punicic Acid a Conjugated Linolenic Acid Inhibits TNFa-Induced Neutrophil Hyperactivation and Protects from Experimental Colon Inflammation in Rats. PLoS ONE, v. 4, n. 7, p. e6458-e6469, 2009.

BRASIL. Ministério da Saúde. Agência Nacional de Vigilância Sanitária - ANVISA. Resolução nº 833, 28 de março de 2007. Resolve Determinar a apreensão, em todo território nacional, de todos os lotes do produto ácido linoléico conjugado - CLA, por não possuir registro no Ministério da Saúde. Diário Oficial da União, Brasília, DF, 29 mar. 2007. Seção 1, p. 68. Disponível em: <http://elegis.anvisa. gov.br/leisref/public/showAct.php?id=26272\&mode=PRINT_ VERSION>. Acesso em: 14 mar. 2010.

$\mathrm{CAO}$, Y. et al. Differential incorporation of dietary conjugated linolenic and linoleic acids into milk lipids and liver phospholipids in lactating and suckling rats. Journal of Nutritional Biochemistry, v. 20, n. 9, p. 685-693, 2009.

CAO, Y. et al. Identification and Characterization of Conjugated Linolenic Acid Isomers by Ag+-HPLC and NMR. Journal of Agricultural and Food Chemistry, v. 54, n. 24, p. 9004-9009, 2006.

CARVALHO, E. B. T. et al. In vivo evaluation of the effect of supplementation of isomers of conjugated linoleic acid (CLAs). Brazilian Journal of Pharmaceutical Sciences, v. 45, sup. 1, p. 41, 2009.

CHARDIGNY, J. M. et al. Effect of Conjugated FA on Feed Intake, Body Composition, and Liver FA in Mice. Lipids, v. 38, n. 9, p. 895-902, 2003.

CHEN, J. et al. Isomerization of conjugated linolenic acids during methylation. Chemistry and Physics of Lipids, v. 150, n. 2, p. 136-142, 2007.

CHRISTIE, W. W.; DOBSON, G.; ADLOF, R. O. A Practical Guide to the Isolation, Analysis and Identification of Conjugated Linoleic Acid. Lipids, v. 42, n. 12, p. 1073-1084, 2007.

COAKLEY, M. et al. Inhibitory Effect of Conjugated $\alpha$-Linolenic Acid from Bifidobacteria of Intestinal Origin on SW480 Cancer Cells. Lipids, v. 44, n. 3, p. 249-256, 2009.

CZAUDERNA, M.; KOWALCZYK, J.; KORNILUK, K. Effect of dietary conjugated linoleic acid and selenized yeast on the concentration of fatty acids and minerals in rats. Archives of Animal Nutrition, v. 61, n. 2, p. 135-150, 2007.

DHAR, P. et al. Dietary Comparison of Conjugated Linolenic Acid (9cis, 11trans, 13trans) and $\alpha$-Tocopherol Effects on Blood Lipids and Lipid Peroxidation in Alloxan-Induced Diabetes Mellitus in Rats. Lipids, v. 41, n. 1, p. 49-54, 2006.

DHAR, P.; GHOSH, S.; BHATTACHARYYA, D. K. Dietary effects of conjugated octadecatrienoic fatty acid ( 9 cis, 11trans, 13trans) levels on blood lipids and nonenzymatic in vitro lipid peroxidation in rats. Lipids, v. 34, n. 2, p. 109-114, 1999. 
FAGALI, N.; CATALÁ, A. Antioxidant activity of conjugated linoleic acid isomers, linoleic acid and its methyl ester determined by photoemission and DPPH techniques. Biophysical Chemistry, v. 137, n. 1, p. 56-62, 2008.

GOEDECKE, J. H. et al. Conjugated Linoleic Acid Isomers, $t 10 c 12$ and $c 9 t 11$, are Differentially Incorporated into Adipose Tissue and Skeletal Muscle in Humans. Lipids, v. 44, n. 11, p. 983-988, 2009.

GROSSMANN, M. E. et al. Eleostearic Acid Inhibits Breast Cancer Proliferation by Means of an Oxidation-Dependent Mechanism. Cancer Prevention Research, v. 2, p. 879-886, 2009.

HONTECILLAS, R. et al. Activation of PPAR $\gamma$ and $\alpha$ by Punicic Acid Ameliorates Glucose Tolerance and Suppresses Obesity-Related Inflammation. Journal of the American College of Nutrition, v. 28, n. 2, p. 184-195, 2009.

HONTECILLAS, R. et al. Catalpic acid decreases abdominal fat deposition, improves glucose homeostasis and upregulates PPAR a expression in adipose tissue. Clinical Nutrition, v. 27, n. 5, p. 764-772, 2008.

HUR, S. J.; PARK, G. B.; JOO, S. T. Biological activities of conjugated linoleic acid (CLA) and effects of CLA on animal products. Livestock Science, v. 110, n. 3, p. 221-229, 2007.

IGARASHI, M.; MIYAZAWA, T. Newly recognized cytotoxic effect of conjugated trienoic fatty acids on cultured human tumor cells. Cancer Letters, v. 148, n. 2, p. 173-179, 2000.

IGARASHI, M.; MIYAZAWA, T. Preparation and fractionation of conjugated trienes from alpha-linolenic acid and their growthinhibitory effects on human tumor cells and fibroblasts. Lipids, v. 40, n. 1, p. 109-113, 2005.

IWABUCHI, M.; KOHNO-MURASE, J.; IMAMURA, J. $\Delta 12$-Oleate Desaturase-related Enzymes Associated with Formation of Conjugated trans $-\Delta 11$, cis- $\Delta 13$ Double Bonds. The Journal of Biological Chemistry, v. 278, n. 7, p. 4603-4610, 2003.

KENNEDY, A. et al. Antiobesity mechanisms of action of conjugated linoleic acid. Journal of Nutritional Biochemistry, v. 21, n. 3, p. 171-179, 2010.

KINAMI, T. et al. Occurrence of Conjugated Linolenic Acids in Purified Soybean Oil. Journal of the American Oil Chemists' Society, v. 84, n. 1, p. 23-29, 2007.

KOBA, K. et al. Dietary Conjugated Linolenic Acid in Relation to CLA Differently Modifies Body Fat Mass and Serum and Liver Lipid Levels in Rats. Lipids, v. 34, n. 4, p. 343-350, 2002.

KOBA, K. et al. Genetically Modified Rapeseed Oil Containing cis-9, trans-11, cis-13-Octadecatrienoic Acid Affects Body Fat Mass and Lipid Metabolism in Mice. Journal of Agricultural and Food Chemistry, v. 55, n. 9, p. 3741-3748, 2007.

KOBA, K.; BELURY, M. A.; SUGANO, M. Potential health benefits of conjugated trienoic acids. Lipid Technology, v. 19, n. 9, p. 200-203, 2007.

$\mathrm{KOHNO}$, H. et al. Pomegranate seed oil rich in conjugated linolenic acid suppresses chemically induced colon carcinogenesis in rats. Cancer Science, v. 95, n. 6, p. 481-486, 2004a.

$\mathrm{KOHNO}, \mathrm{H}$. et al. Dietary seed oil rich in conjugated linolenic acid from bitter melon inhibits azoxymethane-induced rat colon carcinogenesis through elevation of colonic PPARgamma expression and alteration of lipid composition. International Journal of Cancer, v. 110, n. 6, p. 896-901, 2004b.

KRAMER, J. K. G. et al. Analysis of conjugated linoleic acid and trans 18:1 isomers in synthetic and animal products. American Journal Clinical Nutritrion, v. 79, p. 1137S-1145S, 2004.
KRAMER, J. K. G. et al. Distributions of conjugated linoleic acid (CLA) isomers in tissue lipid classes of pigs fed a commercial CLA mixture determined by gas chromatography and silver ion-high-performance liquid chromatography. Lipids, v. 33, n. 6, p. 549-558, 1998.

KÝRALAN, M.; GÖLÜKCÜ, M.; TOKGÖZ, H. Oil and Conjugated Linolenic Acid Contents of Seeds from Important Pomegranate Cultivars (Punica granatum L.) Grown in Turkey. Journal of the American Oil Chemists' Society, v. 86, n. 10, p. 985-990, 2009.

La FUENTE, M. A.; LUNA, P.; JUÁREZ, M. Chromatographic techniques to determine conjugated linoleic acid isomers. Trends in Analytical Chemistry, v. 25, n. 9, p. 917-926, 2006.

LAM, C. K. et al. Conjugated and non-conjugated octadecaenoic acids affect differently intestinal acyl coenzyme A: Cholesterol acyltransferase activity. Atherosclerosis, v. 198, n. 1, p. 85-93, 2008.

MANCINI, D. A. P.; MANCINI-FILHO, J. Prevenção de Reações Oxidativas: antioxidantes nos vegetais de consumo humano. In: DE ANGELIS, R. C. (Ed.) A importância dos alimentos vegetais na proteção da saúde: fisiologia da nutrição protetora e preventiva de enfermidades degenerativas. 2. ed. São Paulo: Atheneu, 2005. cap. 36, p. 206-214.

MARTINS, S. V. et al. Serum adipokine profile and fatty acid composition of adipose tissues are affected by conjugated linoleic acid and saturated fat diets in obese Zucker rats. British Journal of Nutrition, v. 103, n. 6, p. 869-878, 2010.

McAFEE, A. J. et al. Red Meat consumption: An overview of the risks and benefits. Meat Science, v. 84, n. 1, p. 1-13, 2010.

McFARLIN, B. K.; STROHACKER, K. A.; KUEHT, M. L. Pomegranate seed oil consumption during a period of high-fat feeding reduces weight gain and reduces type 2 diabetes risk in CD-1 mice. British Journal of Nutrition, v. 102, n. 1, p. 54-59, 2009.

MELO, I. L. P. et al. Avaliação da estabilidade do óleo da semente de romã (Punica granatum L.). In: SIMPÓSIO DE CIÊNCIA E TECNOLOGIA DE ALIMENTOS; CONGRESSO DO INSTITUTO NACIONAL DE FRUTOS TROPICAIS, 2., 2010, Aracaju. Avanços em Tecnologia de Alimentos... Aracaju, 2010.

MIRMIRAN, P. et al. Effect of pomegranate seed oil on hyperlipidaemic subjects: a double-blind placebo-controlled clinical Trial. British Journal of Nutrition, in press.

MITCHELL, P. L.; McLEOD, R. S. Conjugated linoleic acid and atherosclerosis: studies in animal models. Biochemistry Cell Biology, v. 86, n. 4, p. 293-301, 2008.

MOUTSIOULIS, A. A. et al. Human breast milk enrichment in conjugated linoleic acid after consumption of a conjugated linoleic acid-rich food product: a pilot study. Nutrition Research, v. 28, n. 7, p. 437-443, 2008.

MUKHERJEE, C. et al. Dietary Effects of Punicic Acid on the Composition and Peroxidation of Rat Plasma Lipid. Journal of Oleo Science, v. 51, n. 8, p. 513-522, 2002.

NAGAO, K.; YANAGITA, T. Bioactive lipids in metabolic syndrome. Progress in Lipid Research, v. 47, n. 2, p. 127-146, 2008.

NAGAO, K.; YANAGITA, T. Conjugated fatty acids in food and their health benefits. Journal of Bioscience and Bioengineering, v. 100, n. 2, p. 152-157, 2005.

NOGUCHI, R. et al. Dietary Effects of Bitter Gourd Oil on Blood and Liver Lipids of Rats. Archives of Biochemistry and Biophysics, v. 396, n. 2, p. 207-212, 2001.

PARIZA, M. W.; PARK, Y.; COOK M.; The biologically active isomers of conjugated linoleic acid. Progress in Lipid Research, v. 40, n. 4, p. 283-298, 2001. 
PARK, Y. Conjugated linoleic acid (CLA): Good or bad trans fat? Journal of food composition and analysis, v. 22S, p. S4-S12, 2009.

PARK, Y.; PARIZA, M. W. Mechanisms of body fat modulation by conjugated linoleic acid (CLA). Food Research International, v. 40, n. 3, p. 311-323, 2007.

PLOURDE, M. et al. Absorption and metabolism of conjugated a-linolenic acid given as free fatty acids or triacylglycerols in rats. Nutrition \& Metabolism, v. 3, n. 8, 2006.

RAHMAN, M. M. et al. Conjugated linoleic acid (CLA) prevents age-associated skeletal muscle loss. Biochemical and Biophysical Research Communications, v. 383, n. 4, p. 513-518, 2009.

RAINER, L.; HEISS, C. J. Conjugated linoleic acid: Health implications and effects on body composition. Journal American Diet Association, v. 104, n. 6, p. 963-968, 2004.

REYNOLDS, C. M.; ROCHE, H. M. Conjugated linoleic acid and inflammatory cell signaling. Prostaglandins, Leukotrienes and Essential Fatty Acids, v. 82, n. 4-6, p. 199-204, 2010.

SAHA, S. S.; GHOSH, M. Comparative study of antioxidant activity of $a$-eleostearic acid and punicic acid against oxidative stress generated by sodium arsenite. Food and Chemical Toxicology, v. 47, n. 10, p. 2551-2556, 2009.

SANTOS-ZAGO, L. F.; BOTELHO, A. P.; OLIVEIRA, A. C. Os efeitos do ácido linoléico conjugado no metabolismo animal: avanço das pesquisas e perspectivas para o futuro. Revista de Nutrição, v. 21, n. 2, p. 195-221, 2008.

SASSANO, G. et al. Analysis of pomegranate seed oil for the presence of jacaric acid. Journal of the Science of Food and Agriculture, v. 89, n. 6, p. 1046-1052, 2009.

SCHUBERT, S. Y.; LANSKY, E. P.; NEEMAN, I. Antioxidant and eicosanoid enzyme inhibition properties of pomegrante seed oil and fermented juice flavonoids. Journal of Ethnopharmacology, v. 66, n. 1, p. 11-17, 1999.

SUBBAIAH, P. V. et al. Differential effects of conjugated linoleic acid isomers on the biophysical and biochemical properties of model membranes. Biochimica et Biophysica Acta, v. 1798, n. 3, p. 506-514, 2010.

SUZUKI, R. et al. Cytotoxic Effect of Conjugated Trienoic Fatty Acids on Mouse Tumor and Human Monocytic Leukemia Cells. Lipids, v. 36, n. 5, p. 477-482, 2001.

TRAN, H. N. A. et al. Pomegranate (punica granatum) seed linolenic acid isomers: concentration-dependent modulation of estrogen receptor activity. Endocrine Research, v. 35, n. 1, p. 1-16, 2010.

TSOFLIOU, F. et al. Modulation of fasted and postprandial plasma lipids in healthy volunteers by a dietary mixture of omega-3 fatty acids and conjugated linoleic acid. Journal of Food Lipids, v. 16, n. 4, p. 499-513, 2009.

TSUZUKI, T. et al. Conjugated Linolenic Acid Is Slowly Absorbed in Rat Intestine, but Quickly Converted to Conjugated Linoleic Acid. The Journal of Nutrition, v. 136, n. 8, p. 2153-2159, 2006.

TSUZUKI, T. et al. Tumor growth suppression by a-eleostearic acid, a linolenic acid isomer with a conjugated triene system, via lipid peroxidation. Carcinogenesis, v. 25, n. 8, p. 1417-1425, 2004a.
TSUZUKI, T. et al. $\alpha$-Eleostearic Acid (9Z11E13E-18:3) Is Quickly Converted to Conjugated Linoleic Acid (9Z11E-18:2) in Rats. The Journal of Nutrition, v. 134, n. 10, p. 2634-2639, 2004 b.

TSUZUKI, T.; KAWAKAMI, Y. Tumor angiogenesis suppression by $\alpha$-eleostearic acid, a linolenic acid isomer with a conjugated triene system, via peroxisome proliferator-activated receptor $\gamma$. Carcinogenesis, v. 29, n. 4, p. 797-806, 2008.

WAHLE, K. W. J.; HEYS, S. D.; ROTONDO, D. Conjugated linoleic acids: are they beneficial or detrimental to health? Progress in Lipid Research, v. 43, n. 6, p. 553-587, 2004.

WALLACE, R. J. et al. Isomers of conjugated linoleic acids are synthesized via different mechanisms in ruminal digesta and bacteria. Journal Lipid Research, v. 48, n. 10, p. 2247-2254, 2007.

WANDERS, A. J. et al. A high intake of conjugated linoleic acid does not affect liver and kidney function tests in healthy human subjects. Food and Chemical Toxicology, v. 48, n. 8, p. 587-590, 2010.

YAMASAKI, M. et al. Dietary effect of pomegranate seed oil on immune function and lipid metabolism in mice. Nutrition, v. 22, n. 1, p. 54-59, 2006.

YANG, L. et al. Oxidative Stability of Conjugated Linolenic Acids. Journal of Agricultural and Food Chemistry, v. 57, n. 10, p. 4212-4217, 2009.

YANG, L. et al. $\alpha$-Linolenic acid but not conjugated linolenic acid is hypocholesterolaemic in hamsters. British Journal of Nutrition, v. 93, n. 4, p. 433-438, 2005.

YASUI, Y. et al. Bitter gourd seed fatty acid rich in $9 c, 11 t, 13 t$ conjugated linolenic acid induces apoptosis and up-regulates the GADD45, p53 and PPAR $\gamma$ in human colon cancer Caco- 2 cells. Prostaglandins, Leukotrienes and Essential Fatty Acids, v. 73, n. 2, p. 113-119, 2005.

YUAN, G. F. et al. Effect of punicic acid naturally occurring in food on lipid peroxidation in healthy young humans. Journal of Science of Food and Agriculture, v. 89, n. 13, p. 2331-2335, 2009 a.

YUAN, G. F. et al. Fatty acid composition in tissues of mice fed diets containing conjugated linolenic acid and conjugated linoleic acid. Journal of Food Lipids, v. 16, n. 2, p. 148-163, 2009 b.

YUAN, G. F. et al. Incorporation and metabolism of punicic acid in healthy young humans. Molecular Nutrition \& Food Research, v. 53, n. 10, p. 1336-1342, 2009c.

YUAN, G. F. et al. $\alpha$-Eleostearic acid is more effectively metabolized into conjugated linoleic acid than punicic acid in mice. Journal of the Science of Food and Agriculture, v. 89, n. 6, p. 1006-1011, 2009d.

YUAN, G. F. et al. Effects of conjugated linolenic acid and conjugated linoleic acid on lipid metabolism in mice. European Journal of Lipid Science and Technology, v. 111, n. 6, p. 537-545, 2009 e.

YUAN, G-F.; YUAN, J. Q.; LI, D.Punicic Acid from Trichosanthes kirilowii Seed Oil Is Rapidly Metabolized to Conjugated Linoleic Acid in Rats. Journal of Medicinal Food, v. 12, n. 2, p. 416-422, 2009.

ZHOU, X. et al. Dietary conjugated linoleic acid increases PPAR $\gamma$ gene expression in adipose tissue of obese rat, and improves insulin resistance. Growth Hormone \& IGF Research, v. 18, n. 5, p. 361-368, 2008.

ZLATANOS, S. N.; LASKARIDIS, K.; SAGREDOS, A. Conjugated linoleic acid content of human plasma. Lipids in Health and Disease, v. 7, p. 34-39, 2008. 